\title{
"Concerts and socials for the promotion of good fellowship": Amateur Pianists Perform ${ }^{1}$
}

\author{
KIRSTINE MOFFAT
}

The words "piano performance" typically conjure up the image of a famed virtuoso playing to a packed concert hall and receiving tumultuous applause. In colonial New Zealand the instrument was certainly associated with professional musicianship. Touring virtuosi, each with the glamour of an international reputation and training, regularly attracted crowds, applause and a generous fee. As early as 1851 the visiting Mrs John Bell enchanted audiences at two piano concerts in Auckland, while Ralph Hood's two "Grand Pianoforte Recitals" were sold out in Wellington in 1885. ${ }^{2}$ The Polish pianist Jan Paderewski's performance of Beethoven "enthralled" Willie Tarling in Christchurch in 1904 and his rendition of Liszt's Rhapsodies in 1927 led Frederick Page to eulogize that "there was a hint of gold in every note." However, for most colonial New Zealanders, the opportunities for hearing such performers were rare. The pianists who entertained audiences were more usually local amateurs whose defining characteristics were versatility and adaptability. They performed solo works; accompanied singers, violinists and flautists; tapped out the rhythms for dances; and alternated between the compositions of classical greats, popular favourites, and the occasional local composition.

Four overlapping motifs underpin this discussion of the indispensability of amateur pianists to a wide range of colonial entertainments, and in its interpretation of each motif, this article elaborates the meaning of "colonial performance." First, both the popularity of the instrument itself and the repertoire performed upon it highlight the transnational nature of early New Zealand society. As Caroline Daley emphasizes, colonial society "bore the cultural imprint of its parent (Britain) and its older white siblings (other white settler societies, including America)." ${ }^{, 4}$ Piano playing and performance in New Zealand reflected the practices of these cultural reference points and models, showing how performance was widely understood across cultural, geographical, and social borders. Second, within this overarching pattern of cultural importation there are distinctively New Zealand nuances and variations evident in piano performance, particularly in relation to Māori interaction with the piano and to the gender and class associations of the instrument. Performance in New Zealand took specific forms and presented new questions for its meanings in a colonial setting. Third, while piano performance was at times associated with social improvement and with raising the tone of colonial culture, amateur performers primarily played to give pleasure and to enhance community and conviviality. Finally, this discussion demonstrates that in colonial New Zealand the word "amateur" did not necessarily denote lack of skill. While some newspaper reports, letters, journals, and novels did deride amateur pianists, most accounts praised the skill and versatility of performers.

The word "amateur," particularly when associated with music, is a contested term. For the lexicographer Dr Hugo Riemann, whose views were quoted in an 1897 edition of the Nelson Evening Mail, the "amateur musician" was to be pitied as "one who has learnt nothing properly." Colonial newspapers at times reinforced this perception, sharing jokes at the amateur pianist's expense:

"I adore that selection from Beethoven; it is a melody that haunts me," said the amateur pianist after a very poor attempt at playing a classic. "And no wonder," whispered one listener to another. "She murdered it; so she deserves to have it haunting her."6 
Many of the most damning criticisms of amateur performers are to be found in fictional satires, such as Clara Cheeseman's ironic depiction of Professor Crasher's "heavy artillery" in A Rolling Stone (1886) and Thorpe Talbot's humorous sketch of Miss Wilks's "earsplitting, inharmonious chords" in Philiberta (1882). A poem in an 1888 issue of the Taranaki Herald likewise depicted amateur piano performances as a tuneless frivolity that kept "fair maidens" from useful domestic work and "harass[ed]" the neighbours with a repetitive "pink-a-punk." 8 An early twentieth-century court case demonstrated that some New Zealanders concurred that piano playing was a form of noise pollution. George Kemble assaulted his neighbour Joseph Henry Crocker after Cocker refused to stop "annoying him by playing the piano" in the next door flat from seven to 11 o'clock each evening. Asked if he were a musician, Crocker replied "Yes, an amateur pianist," which led Kemble's lawyer to exclaim: "Yes, that's the whole trouble, an amateur one." Audiences at amateur concerts also complained about incompetent performers. Mary Webb's visit to the Norsewood homestead near Napier in 1885 was ruined by a painful piano performance: "It was really excruciating and the performer thumped and banged on the unlucky instrument till one did not wonder that things were broken."10

However, these criticisms of amateur talent are the exception rather than the rule. A musical commentator who published under the punning pseudonym of "R. Peggio" took issue with Riemann's unflattering definition of the amateur musician, writing in 1897 that it "is generally conceded that in many instances amateurs have learnt to far better purpose than some professionals" and, indeed, "occasionally outstrip [their] professional brother[s]." For R. Peggio, there is something noble about the amateur's pure "love of music." 11 The amateur, unlike the professional, performs not for acclaim, income, or necessity, but simply for enjoyment. Most accounts of relevant performances share this flattering perception of the amateur as talented, and capable of giving great pleasure to audiences. A review in the Poverty Bay Herald of a performance by the J. Battery Variety Troupe is typical: "One of the attractions of the evening was the first appearance in public in Gisborne of Mr. W. Clarke. This gentleman, acknowledged to be an amateur pianist of the first class, rendered a series of selections from the opera of 'Martha,' which were frequently applauded."12 The relative scarcity of such entertainments may well have made audiences more appreciative. This was certainly the message of an 1883 advertisement in the Hawera \& Normanby Star for a variety concert, which declared that "Manaia people have so little entertainment that this ought to be a pleasant evening." ${ }^{\prime 13}$ However, the Poverty Bay Herald assessment of Clarke's performance as a "rare musical treat" goes beyond all-encompassing delight in any entertainment opportunity to pinpoint the particular pleasures of a specific performance by a gifted pianist. ${ }^{14}$ The cumulative evidence of such remarks (many more of which appear later in this discussion) is indicative of a genuine and widespread perception of the high quality of many amateur performances.

The references to enthusiastic applause and music as a "treat" point not only to the good reputation of most amateur pianists, but also to the many associations between musicmaking and fun. Daley argues that while there was an emphasis on "rational recreation" in the nineteenth century - organized leisure with a focus on improvement - there was an equal recognition of the delights of "irrational recreation," events where "fun rather than fitness was the quest, where laughing was more important than learning, and where desire rather than duty was to the fore." 15 At times the piano was certainly regarded as a means of improving the tone and even the morality of colonial society. Missionaries viewed the instrument as a means of furthering the work of religious conversion and cultural transformation, Lady Martin commenting approvingly that by teaching Māori girls to play the piano and sing Mrs Kemp was assisting in the "divine work" of "civilisation."16 Wiremu Rātana had a similar belief in the connection between religion and music, although in his case 
the piano was important as an accompaniment to cultural performances which "showcase[d] the powerful rhythms and hypnotic subtlety of the culture and raise[d] the profile of the Māori people." ${ }^{17}$ In the secular world, classical concerts were perceived as a form of "rational entertainment," a reviewer in the Otago Colonist predicting that Miss Catherine Redmayne's 1858 "Grand Sacred and Miscellaneous Concert" in Dunedin would "contribute materially to substitute an intellectual amusement in place of [the] grosser pleasure ... of a public house.", On a more private and intimate scale, Hannah Richardson believed that if, "with [her] piano," she could "afford" her brother George sufficient "real pleasure" to keep him from drinking and low company, "all [her] time in learning ha[d] been well spent and [she] could not have a better reward."

This view of the piano as "rational recreation" was relatively rare. Instead, the overwhelming evidence is that the piano was primarily regarded as "a source of fun, pleasure and opportunity." 20 Musicologist Stephanie Pitts argues that musical performance is inherently social, "actively entered into for largely straightforward reasons: having fun, exercising a valued and pleasurable skill, and spending time with like-minding friends." ${ }^{21} \mathrm{~L}$. D. Austin, who settled in New Zealand in 1910, described the amateur pianist as a "small radiating centre capable of spreading the gospel of good music" beyond the parameters of the performer's "private life" to provide pleasure and entertainment for the wider community. ${ }^{22}$ His assessment points to the defining attributes of this kind of colonial performer. The amateur pianist was, first, an individual with a developed sense of musical taste and a degree of skill, capable of recognizing and performing "good music." Second, the amateur pianist, while taking great pleasure in the instrument as a means of self-expression and solitary amusement, did not hoard this talent selfishly but shared the entertainment possibilities of the piano with a wider audience, both within the home and in the "wider community." Finally, Austin emphasizes that the performances of amateur pianists ideally fostered fun, pleasure, and social conviviality.

It is to the various ways in which amateur pianists enhanced colonial leisure that I now turn. Throughout this discussion two threads of my argument are intertwined: the strong links between New Zealand performance traditions and British models, and the subtle nuances of New Zealand variation and innovation. I begin with the home as a centre of family entertainment and circle out to more public concerts and dances in barns, schoolrooms, community halls, and clubs. Some of these gatherings were informal and spontaneous, while others were meticulously planned and more ceremonial. The pianists who charmed audiences with their solo skills, deft accompaniments of songs, and rhythmic dance melodies were as varied as the settings. Children and adults were to be found seated at the keyboard, as were both men and women. Māori were increasingly attracted to the musical possibilities of the piano, as were performers from all socio-economic backgrounds. European music, from both the classical and popular ends of the spectrum, dominated the repertoire of both concerts and dances, although the music of local composers began to be heard.

In a musical context, the word "performance" most usually refers to "performing a ... piece of music ... in front of an audience." 23 However, piano performance can also be a solitary, intimate, private act. At times this kind of piano playing is properly termed "practice," such as the way Hannah Richardson diligently played to improve her skill and master new works, but colonial pianists also played purely for themselves, to "a world of [their] own, to something in [themselves] that had no other means of expression." "24 This sense of the piano as a "devoted companion" and extension of self is powerfully articulated by Elsie Milne, who lived in Masterton in the early twentieth century: "A piano is so wonderful if ya just feeling down in the dumps and you want to fly ... You put into the piano ... you play what you're feeling and you get rid of it ... Because music is simple and 
wonderful." 25 Tia DeNora argues that this kind of performance highlights the way in which music can be "an active ingredient in the organisation of self." 26 For James Courage the answer to the question "What do I live for?" was "My music ... when I am at my piano I am happy." 27 At this most fundamental level of performance the piano was thus associated with joy.

As Pitts argues, performance is about "social [as well as] personal fulfilment," and most accounts of amateur piano playing in colonial New Zealand focus on the communal dimensions of music. The leitmotif of these accounts is the pleasure these performances bring to both pianist and audience. ${ }^{28}$ Within the home amateur pianists entertained their families, at times through playing solo pieces, but more typically through accompanying family singalongs. Music in the home was typically less about a separation between performer and audience and more about performance as a communal act, as is evident in Daisy Collings's reminiscences:

Every Sunday night Mum would sit at that piano, and as the family grew, Dad would stand at her back and he would sing, he couldn't sing but he used to sing! ... and once we got old enough to learn the notes we'd all sing. Dad loved "Kilarney," "Kathleen Mavoureen" ... I'll never forget those nights if I live to be a hundred! They were just fabulous. ${ }^{29}$

Nostalgia for what is perceived to be a simpler, Arcadian world is evident in many memories of family music. Ethel Beauchamp Hazelwood, who grew up in Anakiwa near Picton, loved to lie in bed as a child listening "to someone playing the piano" and her Uncle Clem singing "Anchored" and "Believe me if all those Endearing Young Charms." This "far off" world of childhood is one of "peace and security," the implication being that these qualities are a rarity in the twentieth-century world of her adulthood. ${ }^{30}$ Frank Allen also praises the active way in which colonial New Zealand families had "to make their own amusements." He regards this as superior to the "passive" pleasures of radio and television and emphasizes the way that music "brought the family together" and fostered domestic and social cohesion. ${ }^{31}$ The pianist was frequently at the centre of these family gatherings, picking out the melody on the keyboard so that the singers clustered around the instrument could keep in tune, improvising harmonies when sheet music was unavailable, providing the accompaniments to old favourites, and introducing new songs to the family repertoire.

Beyond the sphere of the family, amateur piano players provided entertainment and enjoyment for a larger social circle in the form of impromptu musical evenings and organized concerts and dances. After Hannah Richardson arrived in Napier in 1859 her brother's house was inundated with regular visitors seeking amusement and entertainment. Richardson's diary entry for 23 April 1859 makes it clear that her Broadwood grand was a particular attraction: "Dr McShane had a headache, he stayed all the afternoon and I played a long time just till it was about dark ... Mr. Tiffen, Mr. Rhodes and Dr Hitchings came to tea ... and then Mr. Tucker ... I played and sang to them till ten o'clock."32 Indeed, the enjoyment visitors experienced seemed to depend on their hostess playing. Mr Tucker dismissed an evening in the company of the "tedious" Russells as "miserable" because "there was no music." 33

Sarah Amelia Courage gives a more detailed description of one such musical evening in nineteenth-century Canterbury. After a formal dinner at Mrs Iscariot's home, the guests repaired to the parlour for music and singing round the "sweet-toned" piano. The highlight of the evening was Mrs Colton's performance: "She played from memory, and chose an air of Schubert's, sweet and pathetic ... [She] played as only a person of cultured taste could play. It was quite the feature of the evening." Courage is alert to the connection between memory and music, writing that the performance "recall[ed] to us...memories of long ago," both 
linking the audience to the world of British culture they had left behind and making them conscious of the distance between settler outpost and imperial centre. ${ }^{34}$ Here, performance was understood as a visible and audible means of upholding and perpetuating British cultural practices.

The type of audience and occasion influenced the nature of the performance. Mrs Iscariot's soiree is a formal gathering and Mrs Colton's performance is the focal point for the guests, who listen in respectful silence and applaud at the end. In contrast, Lel Luckie recalls more spontaneous occasions where conversation, food and music were overlapping rather than separate acts. She remembers that "everybody had a piano, or most people had a piano and we used to have, sort of "go to your place next Sunday night" and the mothers always put supper on for us and we would have music ... you had to make your own fun ... We used to have a great time." 35 Performances at these events shared many of the qualities of family entertainments, with everyone contributing to the music-making and the choice of songs, and the pianist required to provide an accompaniment rather than a solo recital.

The skills of amateur pianists were almost always appreciated, but audiences were not immune to the greater pleasure a really gifted performer could provide. When Sarah Greenwood hosted what she termed "the first Quadrille Party ever known on these shores" in her Motueka home in 1850, the music was provided by the Knyvetts. Greenwood acknowledged that "Mr K. and ... his nice wife played most charmingly," but went on to note that "she is the best performer." " Charlotte Godley's enjoyment of social occasions in 1850s Wellington and Christchurch was likewise enhanced by quality performances. Mrs Eyre, the governor's wife, provides a "treat" that brought back memories of the "drawingroom at home" because she "plays unusually well ... on the pianoforte. ${ }^{, 37}$ Ellen Tripp valued the "beautiful" playing of Samuel Butler so much that she was prepared to ensure his "upsetting" "wild theories" for the "pleasure" his music afforded. ${ }^{38}$ Inadequate performances at times met with censure; Hannah Richardson made Mary Irvine cry when she told her that "she played correctly and in time but without taste." 39 To be fair to Richardson, she was also highly critical of her own playing, chastising herself for her "stupidity" in not being able to "play a note" on Mrs Tyser's square piano. ${ }^{40}$ For musicians like Richardson quality was always the goal.

Many colonial performers had a high self-regard and a consequent expectation that their music should be listened to attentively and lavishly praised. Richardson was infuriated when guests "talked enough to interrupt the singing" and playing. ${ }^{41}$ Her enjoyment of musical evenings was dependent on the amount of attention and appreciation she received, her skill at the keyboard clearly bound up with her sense of self. The praise of Mr Pellier, who "expressed himself much delighted with my playing, [and] said he had heard the first players in Paris but he thought none equaled me," makes her rapturous. ${ }^{42}$ In contrast, $\mathrm{Mr}$ Wogan's rudeness at speaking "in raptures of the grands in Nelson and Wellington he played" while failing to "praise" or "derive pleasure from hearing [her] play" causes resentment. ${ }^{43}$ Likewise, John Waring Saxton, who settled in Nelson in 1842, devoted considerable space in his diary to reactions to his playing. He leaves a musical evening at the Greenwoods' in a huff, offended at a suggestion that "the piano [should be] more subordinate to the voices," but is elated when his "brillian[ce]" at sight reading "Overtures to Masaniello, Bohemian Girl" at a musical evening at the Bells' elicits "outrageous compliments" from his host. $^{44}$

Adela Stewart was a more self-effacing performer. She readily sat at the keyboard to provide the music for a dance in 1879, but wrote that before emigrating she had "never dreamt that [her] limited musical powers would be so acceptable as they proved on this and many similar occasions." " the talents of the "big police-sergeant in muddy top-boots" and the "lady settler" who 
assisted her at the 1879 dance. ${ }^{46}$ At another dance in her Athenree home she entrusted much of the music to Frank, one of her husband's cadets. ${ }^{47}$ The rigorous demands placed on pianists, both in terms of stamina and in terms of repertoire, are illustrated by Stewart's mention of the "twenty-eight dances on the programme," including a Scotch reel, the cotillion and the Sir Roger de Coverley, and "several extras" she and Frank were required to play on her Broadwood grand square piano on this occasion. ${ }^{48}$

Piano performance was a gendered activity. Stewart's vivid picture of the music provided by herself, the lady settler, her husband's cadet and the muddy police-sergeant demonstrates the range of amateur performers who entertained in colonial New Zealand. Contrary to perceptions that the nineteenth-century piano was quintessentially a female instrument - evident in Stevan Eldred-Grigg's observation that "ladies tinkled on the ivories, [while] gentlemen were conversant with the flute or violin" - many New Zealand amateur pianists were male. ${ }^{49}$ The association between these men and piano performance is highlighted in Saxton's diaries, which speak of a predominantly male middle-class social circle who visited each other regularly in order to make music. His entry for 30 September 1846 is typical: "Dr Greenwood ... produced his flute and I played with him on the pianoforte the duet Charmante Gabrielle by Drouet, and then the Concertante Duet by Bucher and Benedict." 50 Helen Young takes issue with the view that the piano was somehow incompatible with masculinity, declaring that "this attitude of music being sissy didn't seem to matter in a place like Hawera." As proof that a man could play the piano without suffering a diminution of his manliness she cites the example of a musical "uncle who was a famous All Black" who did not exhibit a "macho attitude" of disdain for the piano. ${ }^{51}$ In this respect, the tradition of amateur piano performance in New Zealand subtly subverts British conventions and traditions. Historians writing about piano playing in nineteenth-century Britain tend to concur that "gentlemen were not expected to play the piano in the drawing room: the only male pianists were professional.",52

Even in the realm of courtship, nineteenth-century discourses about piano playing as a quintessentially female "skill that would help [women] attract a husband" proved to be reductive in the New Zealand context. ${ }^{53}$ Female performance certainly stirred the passions. One gentleman proposed to pianist Hannah Richardson by leaving a letter in her piano stool, another expressed his affection by asking her for music lessons, and a visiting Māori chief even offered to make Hannah "Queen of the Maoris" if she married him and brought her piano as her dowry ${ }^{54}$ She refused all of these offers, but accepted $\mathrm{Mr}$ Ormond, who captivated her when he "sang a capital song Cousin Tom" while she "played in good time and tune." ${ }^{, 55}$ However, amateur male performers were as alert as their female counterparts to the interconnectivity of pianos and romance. Captain James Duff Hewett wooed the musical Ellen Baker though his talent at the keyboard. The success of his campaign is recorded in Ellen's memoir: "his playing captivated me; so after a few days we were engaged."

The piano could also be a social leveller in colonial New Zealand: enjoyed and played by people from all social classes, it brought together communities in a more egalitarian way than was perhaps possible in the more class-defined mother country. A letter to the editor of the Evening Post in 1887 commented approvingly on the "well furnished" homes of "working men," noting that there was a "piano nearly in all." 57 The hire purchase records of Collier's Music Warehouse confirm that people from a diverse range of occupations and socio-economic groups owned pianos. For example, in 1891 instruments were purchased by contractor George McCarthy, saddler George Kitchen, labourer's wife Margaret Miller and saw-miller Henry Stevens. The experience of Henry Shirley is typical of the wide-spread appeal of the piano. When his family moved to Auckland from England in 1909, Shirley's father bought a piano for "fifty guineas, about twenty times his weekly wage. Looking back this seems like sheer recklessness for a working man ... He must have decided life was 
insupportable without home music." 58 Traditional class associations of the instrument were modified in New Zealand, as they were in America and other settler societies, challenging Max Weber's contention that "in its whole musical essence the piano is a domestic instrument of the bourgeoisie." 59

Similar patterns of imported tradition and local innovation are evident in the musical repertoire of amateur pianists. The sonic world of many settler family and community gatherings was a deliberate recreation of the familiar sounds of "Home." When Elizabeth Caldwell arrived in Nelson in 1853 she was invited out on her first evening because of her reputation as a pianist. When she played her hostess's grand piano and sang an aria from Rossini's La Gaza Ladra, a retired army captain exclaimed: " 'Dear, dear, me. I am enchanted. Arthur boy, what does it remind you of?' 'Of the drawing-room at home, Papa.' 'Ah yes, my boy, so it does me-and of my sister." "60 For many colonial settlers the piano was a tangible reminder of home and an assurance that relocation to a distant land did not mean being shut off entirely from the cultural point of origin. After unpacking her precious Broadwood piano Hannah Richardson declared: "I felt it so elevating that we have in this place of roughness the same source of amusement that the high born in England possess."61 She even goes as far as claiming that "with these London amusements we cannot regret London., 62

The choice of music performed is indicative of the taste and outlook of both performers and audiences. Katherine Raine writes of the way in which "gardening was an important part of the psychological process of coming to feel at home in New Zealand," and music functions in the same way. ${ }^{63}$ Familiarity and nostalgia were the defining characteristics of piano repertoire. Music for solo piano reflected a respect for the classical canon. Sarah Selwyn's library included sonatas by John Christian Bach and suites by Domenico Scarlatti, while the musical Buckland family was fond of Chopin's preludes and owned a brown, leather-bound volume of Haydn's symphonies arranged for piano duets. ${ }^{64}$ Piano accompaniments to songs were particularly popular, from religious music such as Handel's Messiah, to operatic favourites like Mozart's "La ci darem la mano," to popular songs including "Maggie's Secret" by Claribel, "Grandfather's Clock" by H. C. Work, and "Annie Laurie" by Alicia Scott. ${ }^{65}$

While most sheet music during this period was imported, some composers sought to give piano repertoire a more local flavor. Concerts in the Canterbury home of Alice Forrester (who in 1900 became the first New Zealand student to receive a Bachelor of Music degree) and at the Canterbury Women's Club regularly included local works because Forrester was a talented composer. ${ }^{66}$ She found inspiration in the New Zealand natural world, her "Bush Song" opening with a series of tremolos designed to imitate the sound and intonation of the bellbird, and was also drawn to Māori language and Māori rhythms, "Maori Battle Song" mimicking the rhythmic pulse of the haka: "Patua, Patua, Kamate, Hu! / Death to them! Death to them! Bondsmen of Tu!" ${ }^{\prime 67}$ Dancing, sport and war provided the inspiration for other local song writers. While most dance tunes mirrored European forms, the use of New Zealand place names for titles reveals a desire to form a connection between the place of origin and the new land: "Waikato Waltz" by Eduard Bergman; "The Picton Schottische" by Antonio Vannini." ${ }^{, 68}$ Musical eulogies to sport also reflected the popularity of both British sporting pursuits and musical forms. Some, such as Alison Booth and Clara Algar's 1898 "Our Bykes and We" and Jean C. Corbett's 1902 "Ping Pong," had a limited distribution, but others became popular staples, none more so than Ted Secker's 1887 rugby classic "On the Ball.",69 World War I triggered an outpouring of local compositions, such as J. H. Phillpot's recruiting propaganda "The Lion-Heart," which urged New Zealanders to "enlist for service freely" to "aid in Freedom's fight," and Felix Le Roy's 1916 "The Battle of Gallipoli," a "descriptive fantasia for piano" which lamented the Anzac soldiers who died on the beaches. ${ }^{70}$ 
Performance took many forms and was highly prized in Māori culture, and the arrival of the piano opened up new sonic and performance opportunities. Māori composers and performers such as singer Fannie Howie, who performed internationally under the stage name Princess Te Rangi Pai, valued the instrument for both its solo and accompanying possibilities. Settling near Te Kaha in 1904, Howie's "great treasure ... was her grand piano.,"71 Here she composed songs, including the popular "Hine, E Hine," the most European of instruments now being used as a compositional aid for Māori music. ${ }^{72}$ Howie's affection for her piano is representative of a wider narrative of cultural exchange and adaptation. On rare occasions pianos were regarded by Māori as the physical manifestation of an unwelcome and intrusive colonising power, such as a raid on Ellen Hewett's Taranaki farm in the 1860s which resulted in her husband's death and her piano having "part of its fretwork ... broken away by the Māori spears and tomahawks." ${ }^{, 73}$ However, the dominant Maori reaction to the piano was one of increasing enjoyment and appropriation.

This is evident in the way in which amateur Māori pianists embraced the musical possibilities of the piano. Kuini Te Tau's turn of the century Waikouaiti home was the focal point of community entertainment because "we had the piano, you see." At the regular Sunday family gatherings the piano accompanied the singing of "Māori hymns.", "The piano was likewise a feature in the Waiomatatini home of politician Apirana Ngata. Ngata's daughter Hinehou was a "trained pianist who often played the upright piano in the carved and tukutuku decorated Māori Room." As in Te Tau's home, the repertoire was a fusion of European and Māori music. Hinehou enjoyed playing the popular songs of the day, which her father "translated into Māori" for the family to "sing together." Māori delight in the piano is highlighted by Wiremu Kerekere, who grew up in Waihirere. He notes that by the 1920s "the centrepiece of most [Māori] houses was a piano." "77 In his home "[m]usic was always important ... my Mum played the piano, so did Dad ... I was the one who was the most musical ... you don't just play for yourself ... there must be feeling and passion all the time." 78

Beyond the home, amateur pianists of all ages, backgrounds and ethnicities were in much demand at community concerts, socials and dances, held in a diverse range of locations. The precedent for this was, of course, set on the long journey by sea to New Zealand. Passengers travelling with their pianos were valued for the entertainment possibilities they could provide. Captains made room for instruments in the saloon and pianists obliged by playing solo items, accompaniments, and dance music. When Hannah Richardson sailed from England in 1858 on the Evening Star, her piano provided the music for evening dances, the "Quadrilles ... Polkas and 'contra danse' Sir Roger" fostering social interaction between the passengers and helping to keep boredom and homesickness at bay. ${ }^{79}$ As shipping lines became more established, resident pianos became a feature, manufacturers constructing instruments specifically for ships, with small, folding keyboards that could be collapsed when not in use. Elna Jaensson, who emigrated to Dannevirke from Denmark in 1906, was delighted with the entertainments offered on board SS Tongariro, particularly an on-deck concert for which "they carried out a piano and ... played and sang." 80 Pianos were also popular on troop ships, providing soldiers with amusement and a measure of familiarity and comfort. William Messenger, an officer who accompanied the $10^{\text {th }}$ New Zealand Contingent on their voyage to South Africa in 1902 noted that "two pianos have been put on board by the Wellington Corporation." ${ }^{\prime 1}$ Premier Seddon and his family were travelling on the ship and thoroughly enjoyed D Squadron's concert on 24 April, Seddon joining in with the singing.

Once settlers arrived in New Zealand, treasured instruments continued to provide public as well as private pleasure. Whether formal or informal affairs, concerts and dances were of fundamental significance in the lives of communities. Performances provided one of 
the primary forms of entertainment and relaxation in colonial New Zealand and were crucial in fostering a sense of community belonging and identity. They could knit together peoples and highlight their shared heritage and remind them of who they were. Above all, performances brought people together to socialize and have fun. In 1850s Nelson the local schoolroom was the focal point of community life. The schoolroom had no piano, but Elizabeth Caldwell lent her Allison and Allison upright grand for the first public concert to be held in the region. A recent emigrant from Scotland, Caldwell had previously "never dreamed" of performing "in public," but agreed to play and sing. ${ }^{82}$ The programme was typical of such amateur performances, being a variety concert with a mixture of vocal items and instrumental music, and Caldwell provides an invaluable picture of the almost desperate enthusiasm of the settler audience:

The room was densely packed and ... rang with cheers ... the opening overture ... went off with the greatest éclat ... Then came my song, "William Tell." I had recovered from my first shyness and got through it playing my own accompaniment much better than I expected. The applause was furious and encore was demanded and I sang "Jock o' Hazeldean" ... During a short interval ... The impatience of the audience was rather provoking ... so Dr. Greenwood made his bow in front of the curtain saying, "Now my good people have a little patience. We you know are not used to appear and perform in public, and we must have just a little longer rest." "Hurrah!" said the audience, "three cheers for the Doctor."

One elderly Scot congratulated Caldwell afterwards: "Your singing and playing maks me fou' [drunk] without ony drink." 83

Schoolrooms also hosted dances that were eagerly anticipated highlights in frequently sparse social calendars. Both the communal conviviality of the 1907 New Year's social and dance in the Motukaraka schoolroom and the importance of the piano in providing dance music are captured in a newspaper report of the event:

After supper comes the dance. Away with benches and chairs. Away with cups and saucers, the floor is swept and besprinkled with a plentiful supply of candle grease. "Gentlemen take your partners for the first dance." Crash bang goes the sorely tried piano, and away go old and young, dancing for pure joyousness and good humour, all troubles forgotten and sorrow fled like a dream. ${ }^{84}$

Barns and woolsheds were also popular locations for dances. Their size, plentiful floor space and bales of hay for seating made them ideal venues. The only thing lacking was music, a want rectified by borrowing a piano from a nearby homestead. Violinist Richard Hay records that when he, pianist Alf Peters and cornetist A.A. George played for a dance in a woolshed on Brooksdale Station in the 1860s there were "700 present, many of whom came from Invercargill." Such was the relish for the occasion that the musicians played "for twelve solid hours, and not even a spell for supper," although there was a brief pause when a fight broke out between two Irishmen keen to claim the same woman as their partner. ${ }^{85}$ Freeflowing alcohol was a feature of many of these boisterous public events. Agnes Elliot recalled that "much whisky" was consumed at a dance at Skippers in 1912, leading to "delightful ... hilarity." "86

Shops and businesses were likewise appropriated after hours by musicians and dancers. In 1866 the Oamaru Cricket Club hosted an "Amateur Concert" to raise money for equipment in Messers Cargills and McLean's wool store. The piano brought to this unlikely space mostly featured as the accompaniment to glees, such as "Hark the Lark," and solos, such as Blockley's "The Englishman," but also had its moment in the spotlight when two members of the team played a duet of the overture from Mozart's Clemenza di Tito ${ }^{87}$ In early 
twentieth-century Glenorchy Saturday night dances were held in Stan Knowles's garage, which had a wooden tongue-and-groove floor suitable for dancing, although dancers had to be alert to avoid treacherous patches of oil. James Robinson recalls the musical skill of "a Scottish miner called Jock Coutts who could play a sort of jazz music on the piano." 88

Musical ability, not maturity, was the prerequisite for entertaining at dances and concerts. Jennie West was only 11 when she played at a concert given by the Dunedin Glee Club. Her performance of the piano part of a Trio for piano, violin and cello and Dussek's "Sonata in E Flat" received positive reviews in the Morning Herald: "The youthful performer ... made a very favourable impression, the brilliancy and sweetness of her execution giving promise of an exceptional instrumentation. She was most enthusiastically encored." 89 Ruru Karaitiana, who was born in 1909 and educated at St Joseph's Convent School in Dannevirke, was only six when he started playing for Saturday night dances, requiring an apple box in order to reach the keys. ${ }^{90}$

As communities became more established, purpose-built halls became the venues of choice for local entertainments. A report of an "Amateur Concert" held in Greymouth on 25 September 1866 is representative of the aims, repertoire and reception of such events and the versatility required of the pianist. The concert was held to raise money for the local hospital and was a singular success in its financial purpose, raising £47. The programme consisted mainly of British vocal compositions to piano accompaniment. Some were part songs and glees, such as "Now is the Month of Maying" and "See Our Oars with Feathered Spray," while others were solo items, such as Mr Aaronson's rendition of "My Own, My Guiding Star." These were "agreeably varied" by a selection of operatic arias "played on the pianoforte and harmonium" by Mr Vincent. For the reviewer the programme was "judicious," providing variety while remaining "within the capacity of performers," thus successfully avoiding the "frequent and fatal mistake of most amateur concerts to be too ambitions." "1

Frequently the desire of amateur performers to play impressive classical works rather than popular music met with muted enthusiasm from reviewers and audience members. A decided preference for the simple and popular over the challenging and classical underpins a review of an 1877 concert in Oamaru's Masonic Hall. The highlight of the evening was the "exquisite performance on the pianoforte of variations on the always popular air, "Home Sweet Home' by Mrs Newsham," which she "wisely ... substituted for the selection from Mose in Egitto, which appeared in the programme." The rest of the programme was dominated by classical music, such as Beethoven's "Moonlight Sonata" and Haydn's piano trio "Gypsy Rhondo." While acknowledging the skill of the performers, the reviewer pleaded for the "substitution of one or two good ballads as entremets, the musical feast being one of almost too great richness for the general appetite." 92

For colonial New Zealanders with a particular passion for music, opportunities to make and listen to music at concerts, socials and dances did not completely satisfy. They wanted their lives to be fully and regularly filled with music and formed a range of societies and clubs to further that end. The vital importance of the amateur pianist to such societies is illustrated in the early history of the Wanganui Philharmonic Society. When the official accompanist to the Society refused to venture out on a stormy evening in the 1860 s it looked as if a planned concert would have to be cancelled, much to the dismay of both the Philharmonic members and the assembled audience whose appetite for music had triumphed over their dislike of getting wet. However, the conductor spotted 17-year-old Eva Harding in the audience and declared that she would have to play: "She played the whole oratorio through at sight perfectly - at the end they all sang For She's a Jolly Good Fellow and collected forty pounds and presented it to her in a little black velvet bag with silver chain ... It was a triumph."93 
Piano performance was also a feature in clubs with a musical dimension. Dunedin's Orphans Club had strong Lodge connections and an all-male membership. The piano was a constant in all the club's musical performances, accompanying singers, performing chamber duets and trios and playing as part of the orchestra. The sounds of the piano were heard at the beginning and end of each meeting, leading the members in the singing of the national anthem and opening and closing odes. The composer of these odes, pianist Brother F. Walsh, had a tragic history, becoming paralyzed in both arms shortly after arriving in Melbourne to further his piano studies. However, his odes emphasize not only the underlying musical purpose of each gathering, but also the importance of "social pleasures" and "jest galore." 94 The programme for an evening for "The Ladies" once again highlights the interconnectedness of fun and music. One of the opening items featured Brothers J. A. Haggitt (piano), J. Flint (violin) and J. W. Stewart (flute). The accompanying programme note stated that the trio "will scrape, blow into and tickle their respective instruments with a view to forming a melody akin to A Herd Girl's Dream; having accomplished which, they will again combine, this time in a Flower Song (in the hope, maybe, that someone will throw them a bouquet)." 95

The piano was likewise an important compositional and accompanying aid for Māori cultural groups. When Kingi Tahiwi became the director of the Newtown church choir his first act was to replace the pianist. Riria Utiku recalls: "I think he probably upset Wiki Bennett, because she used to play the piano for us, you see, and she didn't have good timing and let it drag." 96 When a cultural club was formed at the church the practices were held at Utiku's home "because ... we had a piano." group. The skills of pianist Jock McEwen were indispensable at both practices and public performances, as Utiku emphasizes: "We were brought up with a piano and I don't think in our time we were any good unless we had a piano." 98

In the contemporary Western world leisure is usually regarded as an entitlement, something to be received rather than actively performed. An ever-expanding plethora of entertainment options is easily obtainable without moving from the couch. With the flick of the remote control or the mouse, screens flicker, sound blasts and a concert, programme or game begins. Beyond the home there has been a corresponding decline in community socializing. Of course people are still drawn together to relax and have fun, but these leisure activities often take place in commercial rather than community spaces, as people meet in cafés, restaurants and bars or attend a sporting or cultural event. Colonial New Zealand was a very different place in this respect. Yes, people frequented hotels, tearooms, sports grounds and cinemas, but they also believed strongly in the need to make their own fun and to foster a sense of community identity. Performance took a central place in the cultural activities of colonial New Zealanders. People gathered in communal spaces, circling out from the intimacy of the home to social spaces such as woolsheds, schoolrooms, community halls, and clubrooms. The activities that took place within these spaces required the participation of members of the community who not only attended events but also made the supper, decorated the parlour and polished the hall floor. Above all, the socials, concerts and dances that leavened the lives of colonial New Zealanders were dependent on the involvement of musicians, particularly the obligatory amateur pianist capable of dashing off a sonata, glee or quadrille. These amateur performers were treasured members of the community, clustered round by singers, applauded and encored by audiences and dancers, praised in newspapers, journals and letters. Because of the presence of the instrument and the talents of performers the daily grind could be briefly set aside, communities could come together, voices could be raised in song, and toes could twirl and tap. 
${ }^{1}$ New Plymouth Philharmonic Choir, Folder D, Taranaki Philharmonic Society, Book of Minutes, ARC2001213/1, Puke Ariki, New Plymouth.

${ }^{2}$ John Mansfield Thomson, The Oxford History of New Zealand Music (Auckland: Oxford University Press, 1991), 29; Programme for Ralph Hood's Second Grand Pianoforte Recital, April 11, 1885, Ephemera Collection, Music 1880-1885, Alexander Turnbull Library, Wellington.

${ }^{3}$ Mona Anderson, A Letter from James (Wellington: A. H. and A. W. Reed, 1972), 182; Frederick Page, A

Musician's Journal, ed. and arranged J. M. Thomson and Janet Paul (Dunedin: John McIndoe, 1986), 43-45.

${ }^{4}$ Caroline Daley, "Modernity, Consumption, and Leisure," in The New Oxford History of New Zealand, ed.

Giselle Byrnes (Melbourne: Oxford University Press, 2009), 425.

${ }_{6}^{5}$ R. Peggio, "Musical Notes," Nelson Evening Mail, July 8, 1897, 2.

${ }^{6}$ Evening Post, March 17, 1934, 18.

${ }^{7}$ Clara Cheeseman, A Rolling Stone (London: Richard Bentley, 1886), vol. 1, 225; Thorne Talbot, Philiberta: A Novel (Melbourne: E. W. Cole, 1882), 322.

8 "The Pink-A-Punk Piano," Taranaki Herald, December 22, 1888, 4.

9 "Music in a Flat," Auckland Star, July 31, 1925, 5.

${ }^{10}$ Webb Family Letters, Mary Webb to Aunt Mary, January 13, 1885, Berry Historical Library, Hawkes Bay Museum, Napier.

${ }^{11}$ R. Peggio, "Musical Notes," 2.

12 "J. Battery Entertainment," Poverty Bay Herald, September 28, 1880, 2.

${ }^{13}$ Hawera \& Normanby Star, January 24, 1883, 2.

14 "J. Battery Entertainment," 2.

${ }^{15}$ Daley, "Modernity," 427, 433.

${ }^{16}$ Lady Martin, Our Maoris (1884; Auckland, Wilson \& Horton, 1950), 28.

${ }^{17}$ Keith Newman, Ratana Revisited, An Unfinished Legacy (Auckland: Reed, 2006), 137.

${ }^{18}$ Peter McIntosh, Research Notes Relating to Miss Redmayne, MISC-MS-1556, Hocken Collections, Dunedin; Otago Colonist, April 2, 1858, April 9, 1858; Otago Witness, April 10, 1858, April 17, 1858.

${ }^{19}$ Mrs J. D. Ormond (married name of Hannah Richardson), Diary 1858-1859, MS 1747, March 3, 1859,

Alexander Turnbull Library, Wellington.

${ }^{20}$ Daley, "Modernity," 438.

${ }^{21}$ Stephanie Pitts, Valuing Musical Participation (Aldershot: Ashgate, 2005), 141.

${ }^{22}$ L. D. Austin, "Reminiscences of the Silent Cinema," Music in New Zealand, 172.

${ }^{23}$ Oxford English Dictionary (Oxford: Oxford University Press, 2013).

${ }_{24}^{24}$ Jane Mander, The Story of a New Zealand River (London: John Lane, 1920), 39-40.

${ }^{25}$ Sarah Mathew, Journal, March 14, 1840, quoted in S. Northcote-Bade, Colonial Furniture in New Zealand

(Wellington, Reed, 1971), 119; "Masterton South Rotary Club Oral History,” Elsie Mabel Milne, OHC-4430,

Tape 1, Side 1, 14.2, Oral History Centre, Alexander Turnbull Library, Wellington.

${ }^{26}$ Tia DeNora, Music in Everyday Life (Cambridge: Cambridge University Press, 2000).

${ }^{27}$ James Francis Courage, Literary and Personal Papers, 1903-1973, ARC-0384, Diary, March 21, 1920,

Hocken Collections, Dunedin.

${ }^{28}$ Pitts, Valuing Musical Participation, 1.

${ }^{29}$ Daisy Collings, LD 0010, Tape 2, Side A, Oral History Archives, Lakes District Museum, Arrowtown.

${ }^{30}$ Ethel Beauchamp Hazelwood, Life at Anakiwa: The First 100 Years, 1863-1963 (Nelson: Lucas Print, 1974), 6.

31 "Nelson and Golden Bay Oral History Project," Frank Allan, OHTnt-0053/03, Tape 3, Side 1, Oral History

Centre, Alexander Turnbull Library, Wellington.

${ }^{32}$ Hannah Richardson, Diary 1859-60, M 93/22, April 23, 1859, Berry Historical Library, Hawkes Bay

Museum.

${ }^{33}$ Richardson, Diary, April 6, 1860.

${ }^{34}$ Sarah Amelia Courage, Lights and Shadows of Colonial Life: Twenty-Six Years in Canterbury New Zealand (1896; Christchurch: Whitcombe and Tombs, 1976, 121-22.

${ }^{35}$ Lel Luckie, LD0061, Tape A, Side 2, Oral History Archive, Lakes District Museum, Arrowtown.

${ }^{36}$ Greenwood Letters, MS GRE, Volume 1, 79, Nelson Provincial Museum.

${ }^{37}$ Charlotte Godley, Letters from Early New Zealand 1850-1853, ed. by John R. Godley (Christchurch:

Whitcombe \& Tombs, 1951), August 29, 1859, 95-96.

${ }^{38}$ Ellen Tripp, My Early Days, quoted in Sarah Ell, The Lives of Pioneer Women in New Zealand: From Their

Letters, Diaries and Reminiscences (Auckland: Bush Press, 1993), 57, 61.

${ }^{39}$ Richardson, Diary, August 2, 1872.

${ }^{40}$ Ibid., February 14, 1859.

${ }^{41}$ Ibid., April 3, 1860. 
42 Ibid., March 26, 1859.

${ }^{43}$ Ibid., April 15, 1859.

${ }^{44}$ John Waring Saxton, Diary: 1841-1851, December 18, 1850, vol. 4, 182; September 4, 1849, vol. 4, 94, qMS

SAX, Nelson Provincial Museum,.

${ }^{45}$ Adela Stewart, My Simple Life In New Zealand (1908; Auckland: Wilson \& Horton, 1971), 65-66.

${ }^{46}$ Ibid., 65-66.

${ }^{47}$ Ibid., 65-66.

${ }^{48}$ Ibid., 67.

${ }^{49}$ Stevan Eldred-Grigg, A Southern Gentry: New Zealanders Who Inherited the Earth (Wellington: A. H. \& A. W. Reed, 1980), 92.

${ }^{50}$ Saxton, Diary, vol. 2, 119

51 “Hawera Music Project," Helen Young, OHA-1933, Abstract, 3-4, Oral History Collection, Alexander Turnbull Library, Wellington.

${ }^{52}$ Nicholas Temperley, "Ballroom and Drawing-Room Music," in The Lost Chord: Essays on Victorian Music, ed. Nicholas Temperley (Bloomington: Indiana UP, 1989), 120.

${ }^{53}$ Laura Vorachek, "“The Instrument of the Century': The Piano as an Icon of Female Sexuality in the

Nineteenth Century", George Eliot-George Henry Lewes Studies 38-39 (2000), 26.

${ }^{54}$ Richardson, Diary, July 28, 1860, April 10, 1860, August 25, 1859, August 21, 1859.

${ }^{55}$ Richardson, Diary, June 10, 1859.

${ }^{56}$ Ellen Hewett, Looking Back or Personal Reminiscences (1910; Hamilton: Rice Print, 1978), 11-12.

${ }^{57}$ Evening Post, May 31, 1887, 4.

${ }^{58}$ Henry Shirley, Just a Bloody Piano Player (Auckland: Price, 1971), 17.

${ }^{59}$ Craig H. Roell, "The Piano in the American Home," in The Arts and the American Home, 1890-1930, eds. Jessica H. Foy and Karal Ann Marling (Knoxville, 1994), 95-110; Judith Tick, "Passed Away is the Piano Girl: Changes in American Musical Life, 1870-1900," in Women Making Music, ed. Judith Tick (Urbana: University of Illinois Press, 1986), 325-48; Max Weber, quoted in Jodi Lustig, "The Piano's Progress: The Piano in Play in the Victorian Novel," in The Idea of Music in Victorian Fiction, eds. Sophie Fuller and Nicky Losseff (Aldershot: Ashgate, 2004), 85.

${ }^{60}$ John Miller, Early Victorian New Zealand: A Study of Racial Tension and Social Attitudes, 1839-52

(Wellington: Oxford University Press, 1974), 174.

${ }^{61}$ Ormond, Diary, March 3, 1859.

62 Richardson, Diary, April 25, 1860.

${ }^{63}$ Katherine Raine, "Domesticating the Land: Colonial Woman's Gardening," in Fragments: New Zealand Social \& Cultural History, eds. Bronwyn Dalley and Bronwyn Labrum (Auckland: Auckland University Press, 2000), 83.

${ }^{64}$ J. M. Thomson, “A Colonial Bouquet-Music from Mrs Selwyn’s Library,” Papers relating to S.H. Selwyn's Musical Library, MS-Papers-5378-263, Alexander Turnbull Library, Wellington; Music Collection, Highwic House, Buckland Family.

${ }^{65}$ Thomson, "A Colonial Bouquet”; Christina Brown Music Collection, Elms Mission House, Tauranga; Euphemia Maxwell Music Collection, Elms Mission House, Tauranga; Anne Lush Music Collection, Ewelme Cottage, Auckland.

${ }^{66}$ Alice May Brodie, Scrapbook, July 27, 1884 - April 17, 1937, Box 1, folder 1, “A Musical Entertainment at the Canterbury Women's Club," August 1931, Canterbury Museum Archive,.

${ }^{67}$ Timaru Herald, March 2, 1900, 2; Alice Forrester (music) and Jessie Mackay (words), "Maoriland," MSPapers-4715-21, Alexander Turnbull Library, Wellington.

${ }^{68}$ Elizabeth Nichol, "In Search of Eduard Bergman: Regimental Bandmaster in the 1860s Waikato Land Wars," Crescendo 71, 7-10; Eduard Bergman, "Waikato Waltz," Special Collections, Auckland Public Library; Antonio Damiano Vannini, "The Picton Schottische," London and Picton, 1884, Picton Museum, Display.

${ }^{69}$ Alison A. Booth and Clara Algar, "Our Bykes and We: A Bicycle Song," Wellington, 1898, National

Archives, Wellington, PC 4, 98/19; Jean C. Corbett, "Ping Pong," Auckland, 1902, National Archives,

Wellington, PC 4, 02/37; Manuscript for "On the Ball," MS-0573, Alexander Turnbull Library, Wellington.

${ }^{70}$ J. H. Phillpot (music) and Gertrude Bailey (words), "The Lion-Heart," Waiouru Army Museum Archives (WAMA) 1997.533; Feliz Le Roy, "The Battle of Gallipoli: Storming the Heights at the Dardanelles by our Australian and New Zealand Heroes" (Melbourne: Dinsdales Music Publishers, 1916), WAMA, 1992.1479.

${ }^{71}$ Florence Harsant, They Called Me Te Maari (Christchurch, Whitcoulls, 1979), 148.

72 Maria Simpson, Research Material for Research Essay on Te Rangi Paea, MS Papers 2002-379-174,

Alexander Turnbull Library, Wellington.

${ }^{73}$ Hewett, Looking Back, 17.

${ }^{74}$ Kuini Te Tau, OHInt-0015/05, Tape 1, Side 2, Oral History Centre, Alexander Turnbull Library, Wellington. 
${ }_{76}^{75}$ Henare Te Raumoa Te Ua, Henare Te Ua: In the Air (Auckland: Reed, 2005), 11.

${ }^{76}$ Te Ua, Henare Te Ua, 14; Ranginui Walker, He Tipua: The Life and Times of Sir Apirana Ngata (Auckland: Viking, 2001), 164.

${ }^{77}$ Wiremu Kerekere, OHInt-0580/1, Abstract, Oral History Centre, Alexander Turnbull Library, Wellington.

${ }^{78}$ Wiremu Kerekere, OHInt-0580/1, Tape1, Side 1, Oral History Centre, Alexander Turnbull Library,

Wellington.

${ }^{79}$ Ormond, Diary, October 19, 1858.

${ }^{80}$ Elna Jaensson, Diary, NZMS 871, April 5, 1906, 17, Special Collections, Auckland City Library.

${ }^{81}$ William Messenger, Diary, April 14, 1902 - July 4, 1902, ARC2002.482, folder 8, Puke Ariki, New

Plymouth.

${ }^{82}$ Elizabeth Taylor Caldwell, Reminiscences, written in 1890 from diaries kept between 1850 and 1861, MS

Papers 1771, folder 04, 17-8, E. Washbourne Collection, Alexander Turnbull Library, Wellington.

${ }^{83}$ Caldwell, Reminiscences, $18-19$.

${ }^{84}$ Rudall Family Scrapbook, A152/1, 1, "Motukaraka," Northland Age report of 1907 New Year's dance, Far North Regional Museum.

${ }^{85}$ Richard Hay, "Old Times in New Zealand," written 1911, MISC-MS-1201, 8, Hocken Collections, Dunedin.

${ }^{86}$ Miss Agnes Elliot, LD 0031, Tape 1, Side A, Oral History Archive, Lakes District Museum, Arrowtown.

${ }^{87}$ 166/9C, Programmes, North Otago Museum.

${ }^{88}$ James Robinson, LD 0083, Tape 1, Side A, Oral History Archive, Lakes District Museum, Arrowtown.

${ }^{89}$ Jennie Macandrew, Memories, Musical and Otherwise (Auckland: Craig \& Lineham, 1941), 4.

${ }^{90}$ Gordon Spittle, "Karaitiana, Rangi Ruru Wananga," from the Dictionary of New Zealand Biography, Te Ara the Encyclopedia of New Zealand, accessed April 1, 2013, http://www.TeAra.govt.nz/en/biographies/5k3/ karaitiana-rangi-ruru-wananga.

${ }^{91}$ The Amateur Concert, September 25, 1866, History House, Greymouth.

${ }^{92}$ North Otago Times, October 17, 1877, 3.

${ }^{93}$ Ruth Crawford, Journal ca. 1861-1881, MS-Papers-1129, 40-41, Alexander Turnbull Library, Wellington.

${ }^{94}$ R. C. T. Evans, A History of Fifty Years: Dunedin's Orphan's Club 1898-1948, 21, Walter James Sinton, Papers, MS-1226/019, Hocken Collections, Dunedin.

${ }^{95}$ McNab Collection, Dunedin Public Library.

${ }^{96}$ Riria Utiku, OHInt-0600/11, Tape 1, Side 1 transcript, 3, Oral History Collection, Alexander Turnbull Library, Wellington.

${ }^{97}$ Utiku, 4.

${ }^{98}$ Utiku, Tape 1, Side 2, 8. 